\title{
The Implementation of Character Education through Online Learning During the Pandemic
}

\author{
Ana Khalimatul Muna ${ }^{1^{*}}$, Wahyu Lestari ${ }^{2}$, Prisma Adi Putra ${ }^{3}$ \\ ${ }^{1}$ Pendidikan Dasar, Universitas Negeri Semarang, Semarang, Indonesia \\ 2,3 Fakultas Pendidikan Seni, Universitas Negeri Semarang, Semarang, Indonesia \\ *Email: anakhalimatulm@students.unnes.ac.id ${ }^{1}$, \\ wahyupyarlestari@mail.unnes.ac.id², prismaadiputra25@gmail.com³
}

\begin{abstract}
Pada masa pandemi Covid-19 kegiatan pembelajaran dilakukan secara daring. Meskipun melalui pembelajaran daring diharapkan pendidikan karakter tetap dilaksanakan oleh guru mengingat pentingnya pendidikan karakter bagi generasi muda. Tujuan dari penelitian ini adalah untuk menganalisis implementasi pendidikan karakter melalui pembelajaran daring selama masa pandemi di sekolah dasar. Metode penelitian yang digunakan adalah penelitian kualitatif dengan pendekatan deskriptif dengan teknik pengumpulan data melalui kegiatan observasi dan wawancara. Subjek penelitian adalah Guru kelas V SD. Hasil penelitian menunjukkan bahwa pendidikan karakter yang diberikan oleh guru melalui aplikasi Zoom yaitu guru membiasakan siswa untuk berdoa dan mengucap salam sebelum dan sesudah pembelajaran dimulai, guru membiasakan siswa untuk mengenakan pakain yang rapi dan sopan, dan guru memberikan nasehat yang sifatnya mampu menumbuhkan karakter positif bagi siswa. Pendidikan karakter yang diberikan guru melalui aplikasi WhatsApp yaitu guru mengirimkan quote yang memiliki nilai karakter di dalamnya secara rutin, guru membiasakan siswa untuk menggunakan bahasa yang sopan ketika mengirim pesan maupun mengirim tugas di group, dan guru mengirimkan video atau link video tentang pendidikan karakter kepada siswa secara rutin. Berdasarkan hasil penelitian, dapat ditarik simpulan bahwa implementasi pendidikan karakter melalui pembelajaran daring telah dilaksanakan oleh guru kelas $\mathrm{V}$ dengan memanfaatkan aplikasi yang terkoneksi dengan internet yaitu aplikasi Zoom dan WhatsApp.
\end{abstract}

Kata Kunci: Pendidikan Karakter, Pembelajaran Daring

\begin{abstract}
During the Covid-19 pandemic, learning activities are carried out online. Although through online learning, it is hoped that teachers will still teach character education, considering the importance of character education for the younger generation. This study aimed to analyze the implementation of character education through online learning during the pandemic in elementary school. The research method used is qualitative research with a descriptive approach with data collection techniques through observation and interviews. The subject of the study was the fifth-grade elementary school teacher. The results show that the character education provided by the teacher through the Zoom application is that the teacher familiarizes students with praying and greeting before and after learning begins, the teacher familiarizes students with wearing neat and polite clothes. The teacher gives advice that can foster positive character for students. The teacher provides character education through the WhatsApp application. The teacher sends quotes with character values regularly, familiarizes students with using polite language when sending messages or assigning assignments in groups, and sends videos or video links about character education to students. Based on the study results, it can be concluded that fifth-grade teachers have implemented character education through online learning by utilizing internet-connected applications, namely Zoom and WhatsApp applications.
\end{abstract}

Keywords: Character Education, Online Learning

\footnotetext{
${ }^{*}$ Corresponding author.

Received May 12, 2021; Accepted June 25, 2021; Available online October 25, 2021

This is an open access article under the CC BY-SA license. Copyright $@ 2021$ by Author. Published by Universitas Pendidikan Ganesha.
} 


\section{INTRODUCTION}

In the 2013 Curriculum, the achievement of learning objectives requires students' competence in knowledge, skills, and attitudes (Nugroho et al., 2020). Implementing the 2013 curriculum is one of the government's efforts to intensify character education for the younger generation. Character education is considered important for the sustainability of the younger generation. In school, we often encounter various problems related to students' character, which are indicated by student delinquency, such as bullying behavior, lack of student discipline in obeying school rules, and lack of student manners when communicating with teachers or someone older. It is a sign that students are now experiencing a worrying moral decline. It is one of the effects of globalization. Therefore it is necessary to have a character education to overcome the problem of moral crisis.

Character education is a conscious effort to realize virtue, namely objectively good human qualities, good for individuals, and good for society (Apriani \& Wangid, 2015; Fibrianto \& Yuniar, 2020; Muhaemin \& Ihwah, 2019). Character education is an effort to develop certain characters so that students can grow their distinctive characters when living their lives. It can be said that character refers to a series of attitudes, behaviors, motivations, and skills. Based on the opinions of several experts, it can be concluded that character education is an effort made to instill certain character values in students so that students have a good personality. Character education is closely related to moral education to develop student behavior that does not conflict with applicable norms and rules (Mahardi et al., 2019; Nurgiansyah, 2021; Sujatmiko et al., 2019; Tanto et al., 2019).

Character education in the era of globalization needs to be done due to the emergence of social phenomena that have emerged lately, which are very worrying. The phenomenon of violence in solving problems has become a common thing. Coercion of will between one group to another is considered normal. Acts of violence and human rights violations, immoral behavior and dishonesty continue to adorn the life of our nation. The number of criminal cases among students indicates a decline in moral values (moral decadence) and student character. Based on the phenomena that have occurred, it can be seen that character education needs to be carried out by teachers to students as early as possible. It is hoped that it will impact students' daily behavior.

In 2020 education in Indonesia transformed. This transformation is due to government policies that prohibit face-to-face learning activities. It is due to the Covid-19 pandemic that is giving up worldwide. Corona Virus (Covid-19) is a very fast transmission rate. To break the chain of the spread of Covid-19, the government took a policy in education by eliminating direct learning activities. Learning activities are carried out by implementing distance learning by utilizing technological advances known as online learning. Online learning is learning that uses the internet network with accessibility, connectivity, flexibility and the ability to give rise to various types of learning interactions (Kurniawati et al., 2019; Rosmiati \& Lestari, 2021; Sari et al., 2020; Sudibjo, 2019; Yuliani \& Saputri, 2021). Online learning is done through a computer or smartphone device that is connected to an internet connection. Learning activities can use the Zoom application, Google Meet, Whatsapp, and other applications.

The implementation of character education during the Covid-19 pandemic was difficult because of several things, including the limitations of teachers in providing supervision and the limitations of teachers in interacting with students. However, because of the importance of character education, it must still be implemented, namely by innovating the implementation of character education. Character education can be inserted into the learning process. Learning is an educational process carried out to get what is expected in educating, teaching, and guiding to produce something better (Astuti et al., 2021). Online learning activities carried out by teachers must still pay attention to the quality of learning by making learning fun. Fun learning can help optimize students' abilities (Sujito et al., 2015). It was done by the fifth-grade teacher of SD 3 Kirig, who implemented character education by utilizing the technology used in online learning. This study aims to analyze the implementation of character education through online learning during the pandemic in elementary schools.

\section{METHOD}

The method used in this research is qualitative research with a descriptive approach. This study describes the implementation of character education through online learning during the Covid-19 pandemic. This research was conducted at SD 3 Kirig, located at JI. Raya Krapyak, RT 04/RW 02, Kecamatan Mejobo, Kabupaten Kudus. The subject of this research is 
the fifth-grade teacher of SD 3 Kirig. The instruments in this study were observations and interviews. The data collection technique in this study was by observing the description of the implementation of character education through online learning during the Covid-19 pandemic, structured interviews with the fifth-grade teacher of SD 3 Kirig, and documentation in the form of data collection related to the implementation of character education through online learning. The data validity technique in this study uses observational persistence and data triangulation. The data analysis technique uses data reduction, presentation, and verification to conclude. The data analysis technique refers to the Miles and Huberman model. Activities in qualitative data analysis are carried out interactively and take place continuously until complete so that the data is saturated (Miles \& Huberman, 2016).

\section{RESULT AND DISCUSSION}

Character education was implemented through online learning during the Covid-19 pandemic. Researchers conducted interviews related to how the implementation of character education. The following is an excerpt from the researcher's interview with the fifth-grade teacher of SD 3 Kirig. Based on the interview results, the researcher can discover that character education is implemented by utilizing applications used during online learning. The applications used are the Zoom and WhatsApp applications. Through the Zoom application, teachers conduct face-to-face learning online. Implementation of character education is done by habituation of students to pray and say greetings before and after learning. In addition, the teacher also gives messages or advice that can build student character, such as messages always to respect and appreciate parents, teachers, and older people. Another message is always to carry out worship and get closer to God. Another message is not to leave their responsibilities as students, namely studying and doing the assigned tasks, with full responsibility. The teacher also asks students to wear neat and polite clothes during the Zoom lesson.

The use of the teacher's WhatsApp application is to send a quote that has character education in it, such as the quote "Everyone who plants will reap what they plant. So, plant goodness (do good) so that you also reap goodness "," Love and respect your parents and do good while you can still hear his voice "," Be hard on yourself (diligent study), so that your future becomes easier ", etc. . In addition to the quote, the teacher also instills in students the habit of using polite language when sending messages. The teacher requires students to convey greetings when sending messages for the first time, introduce themselves when submitting assignments, and use polite sentences. In addition, the teacher also carried out the implementation by sending a video or video link about character education. The following is a screenshot of a WhatsApp Group showing the implementation of character education with habituation. WhatsApp Group screenshots when the teacher sends quotes can be seen in Figure 1, screenshots of students using polite language can be seen in Figure 2, and screenshots of teachers sending videos about character education can be seen in Figure 3.

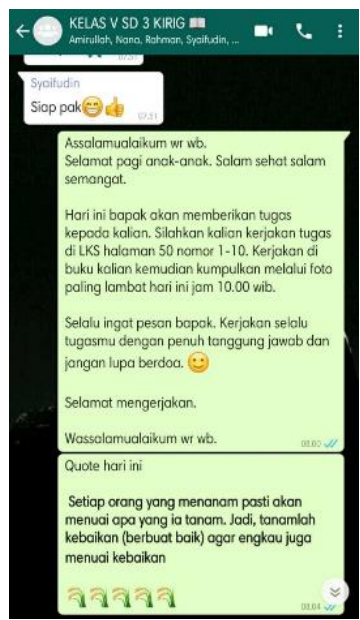

Figure 1. Guru is sending a quote

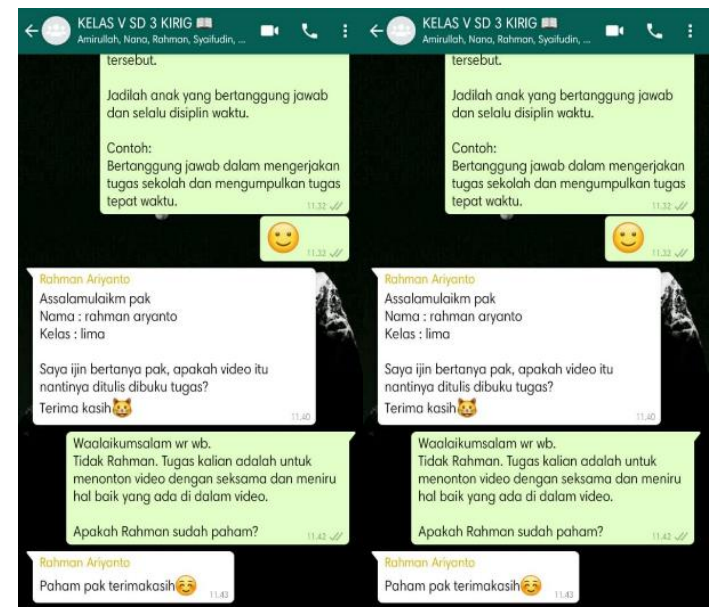

Figure 2. Students use polite language 
IVCEJ, Vol 4 No 2, Tahun 2021

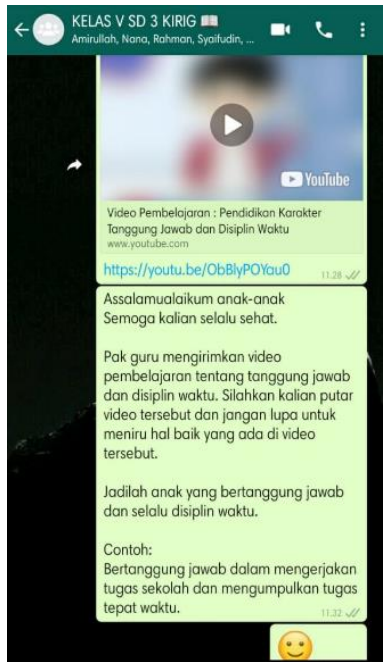

Figure 3. Teacher sending a video about Character Education

The research results on the implementation of character education through online learning for the fifth grade of SD 3 Kirig found that the fifth-grade teacher had implemented character education using the Zoom and WhatsApp applications. The Zoom application was created by Eric Yuan, inaugurated in 2011. This application can be used as a learning medium using video. The Zoom application has a free license but with a time limit of 40 minutes and for a paid license there is no time limit (Haqien \& Rahman, 2020). While WhatsApp is a social media in the form of a chat application that can be used on smartphones (Andjani et al., 2018). In any condition and situation, character education must be instilled. Teachers have implemented character education through habits when learning through the Zoom application.

The habit is the habit of greeting and praying before and after learning. This character education is character education that focuses on students' religious values. By doing these activities, students will be formed character to always remember God by praying. Specifically, religious-based character education refers to the basic values contained in religion, these values can come from the holy book or the example of religious leaders (Arsanti, 2018). Religious attitudes that students usually carry out will be embedded in students and will become a strong inherent character. This religious attitude will later guide students in doing various things. Of course, students' attitudes based on religious attitudes will tend not to deviate from the existing norms. Religious behavior will lead students to act morally and ethically. (Swandar, 2017).

Teachers also carry out the implementation of character education by providing motivation and direction through Zoom regularly. It allows students to apply the character values that the teacher wants to instill. Giving motivation and direction that can shape character is more optimal if given by the teacher. Although parents also have an important role, the teacher plays a more important role. It happens because elementary school students are still strongly indoctrinated by the teacher's words. In general, elementary school students listen to what the teacher says more than their parents say (Rahmat et al., 2017). Therefore, the teacher who is more listened to by students should provide a lot of motivation and direction. The provision of motivation is also intended to foster students' sense of independence both in doing school assignments and assignments at home. Independence is important and needs to be developed in every learning (Sumindar \& Lestari, 2012). Independence is one of the important attitudes that students must have, an independent attitude will encourage students to be more confident in doing various things. The independent attitude instilled at the elementary school level will be a provision for these students to enter a higher level. In addition, independence will also be a provision for students in life, both in the family environment and in the wider community. Independent students will find it easier to face and find solutions to the problems they encounter. One form of self-reliance does not depend on others. Therefore, the value of the character of independence is very important to be applied by teachers. The character of independence is an important value and must be applied through character education in schools to form an independent young generation (Wuryandani et al., 2016). 
Another habit that teachers apply when learning via Zoom is using neat and polite clothes. It is one of the character education instilled by the teacher. This habituation will enable students to cultivate ethics in dressing. Students are expected to know how to dress ethically at certain times and conditions because we know that a person's appearance reflects his personality. Good dress etiquette will encourage students to make good associations as well. Students will know whether the association is good or not when they know the etiquette of dressing from other people. Dress etiquette is one of the ethical aspects in association, as stated by Zakaria in (Andriati \& Hidayati, 2020), social ethics is divided into three aspects, namely: 1) students' language ethics, 2) students' behavior ethics, and 3) students' dress ethics.

In addition to using the Zoom application, teachers also use the WhatsApp application. Character education is implemented by sending a quote containing the character values to the WhatsApp group. One example is in Figure 1 which shows one of the Quotes sent by the teacher to students via the WhatsApp application. The quote is sent by the teacher regularly every day. Using quotes like this will motivate students to do things that can develop a positive character. Motivation is something that students need to have to do everything. Motivation is an impulse that arises in a person consciously or unconsciously (Murtono, 2017). This quote will indirectly give doctrine to students to do the positive things contained in it. The positive doctrine given by the teacher through this quote will routinely form a mindset that will give birth to habits to create a character that is inherent in students.

The teacher also familiarizes students with using polite language when sending chats in WhatsApp groups. One example is in Figure 2. It can be seen that students send a message by paying attention to the etiquette of sending good messages, namely the message begins with a greeting, then introduces themselves, and the contents of the message are also written using polite language. It shows that the implementation of character education carried out by teachers by using polite language has been carried out by students well. These habits will shape students' character always to use the polite language both orally and in writing.

Another implementation of character education carried out by teachers is by sending a video or video link containing character education. It can be seen in Figure 3 . The teacher sends a character education video so that students can find out real examples of actions that can shape character visually. Videos have a special attraction for students. students will be more motivated and will find it easier to remember what good things are contained in the character education videos sent by the teacher. In addition, this video is intended so that students do not get bored in learning activities. The use of videos in character education is very important for students because videos will make students relax because learning is not only an interaction between teachers and students (Mustikaningrum et al., 2020). This is a form of teacher's effort to keep creating fun learning so that students can participate in learning activities even though learning is done online. In this way, teachers can implement character education even though learning is only done online. It proves that teachers can still carry out character education even in difficult circumstances. During a pandemic like this, health is a concern. However, character education also needs to be considered so that the younger generation still has a character that is getting less and less due to globalization.

\section{CONCLUSION}

Fifth-grade teachers have implemented character education through online learning by utilizing internet-connected applications, namely the Zoom and WhatsApp applications. Character education provided by the teacher through the Zoom application is that the teacher familiarizes students with praying and greeting before and after learning begins. The teacher familiarizes students with wearing neat and polite clothes. The teacher gives advice that can foster positive character for students. The teacher provides character education through the WhatsApp application: the teacher regularly sends quotes with character values, familiarizes students with using polite language when sending messages or assignments in groups, and sends videos or video links about character education to students. It indicates that character education has been implemented even though learning is done online.

\section{REFERENCES}

Andjani, A., Ratnamulyani, I., \& Kusumadinata, A. (2018). Penggunaan Media Komunikasi Whatsapp Terhadap Efektifitas Kinerja Karyawan The Use Of Whatsapp Comunication Media To The Effectiveness Of Worker Performance. Jurnal Komunikatio, 4(April). 
https://ojs.unida.ac.id/JK/article/view/1211.

Andriati, N., \& Hidayati, N. (2020). Investigasi Pelaksanaan Bimbingan Kelompok Tentang Etika Pergaulan Siswa di Era Digital. JINOTEP (Jurnal Inovasi Dan Teknologi Pembelajaran): Kajian Dan Riset Dalam Teknologi Pembelajaran, 7(2), 116-123. https://doi.org/10.17977/um031v7i22020p116.

Apriani, A.-N., \& Wangid, M. N. (2015). Pengaruh SSP Tematik-Integratif Terhadap Karakter Disiplin dan Tanggung Jawab Siswa Kelas III SD. Jurnal Prima Edukasia, 3(1), 12-25. https://doi.org/10.21831/jpe.v3i1.4061.

Arsanti, M. (2018). Pengembangan Bahan Ajar Mata Kuliah Penulisan Kreatif Bermuatan NilaiNilai Pendidikan Karakter Religius Bagi Mahasiswa Prodi Pbsi, Fkip, Unissula. KREDO : Jurnal Ilmiah Bahasa Dan Sastra, 1(2), 71-90. https://doi.org/10.24176/kredo.v1i2.2107.

Astuti, Y. T., Lestari, W., \& Cahyono, A. (2021). Sikap Siswa Terhadap Pembelajaran Seni Tari Di Masa Pandemi Covid-19. Jurnal Kajian IImiah, 21(1). https://doi.org/10.31599/jki.v21i1.445.

Fibrianto, A. S., \& Yuniar, A. D. (2020). Peran Budaya Organisasi Dalam Pembentukkan Karakter, Etika Dan Moral Siswa Sma Negeri Di Kota Malang. Jurnal Analisa Sosiologi, 9(1), 267-282. https://doi.org/10.20961/jas.v9i1.41372.

Haqien, D., \& Rahman, A. A. (2020). Pemanfaatan Zoom Meeting untuk Proses Pembelajaran pada Masa Pandemi Covid-19. SAP (Susunan Artikel Pendidikan), 5(1). https://doi.org/10.30998/sap.v5i1.6511.

Kurniawati, M., Santanapurba, H., \& Kusumawati, E. (2019). Penerapan Blended Learning Menggunakan Model Flipped Classroom Berbantuan Google Classroom Dalam Pembelajaran Matematika SMP. EDU-MAT: Jurnal Pendidikan Matematika, 7(1), 8-19. https://doi.org/10.20527/edumat.v7i1.6827.

Mahardi, I. P. Y. S., Murda, I. N., \& Astawan, I. G. (2019). Model Pembelajaran Teams Games Tournament Berbasis Kearifan Lokal Trikaya Parisudha Terhadap Pendidikan Karakter Gotong Royong Dan Hasil Belajar IPA. Jurnal Pendidikan Multikultural Indonesia, 2(2), 98. https://doi.org/10.23887/jpmu.v2i2.20821.

Miles, M. B., \& Huberman, A. M. (2016). Miles, M. B., \& Huberman, A. M. (1994). Qualitative data analysis: An expanded sourcebook. In Nursing standard (Royal College of Nursing (Great Britain) : 1987) (Vol. 30, Issue 25).

Muhaemin, M., \& Ihwah, A. (2019). Pengaruh Pendidikan Pramuka Terhadap Pembentukan Karakter Religius Pada Anggota Pramuka. Al-Iltizam: Jurnal Pendidikan Agama Islam, 4(1), 111-120. https://doi.org/10.33477/alt.v4i1.757.

Murtono. (2017). Merencanakan dan Mengelola Model-Model Pembelajaran Inovatif (Student Center Learning). Wade Group.

Mustikaningrum, G., Pramusinta, L., Ayu, S., \& Umar, M. (2020). Kurikulum Dan Metode Pembelajaran Pada Masa Pandemi Covid-19 the Implementation of Character Education Integrated To Curriculum and Learning Methods During Covid-19 Pandemic. AULADUNA: Jurnal Pendidikan Dasar Islam, 7(2), 154-164. https://primary.ejournal.unri.ac.id/index.php/JPFKIP/article/view/8448.

Nugroho, M. A., Florentinus, T. S., \& Lestari, W. (2020). Pengembangan Instrumen Penilaian Materi Musik Ansambel Berbasis Android bagi Siswa SMP. 2019.

Nurgiansyah, T. H. (2021). Pendidikan Pancasila Sebagai Upaya Membentuk Karakter Jujur. Jurnal Pendidikan Kewarganegaraan Undiksha, 9(1), 33-41. https://doi.org/10.23887/jpku.v9i1.31424.

Rahmat, N., Sepriadi, S., \& Daliana, R. (2017). Pembentukan Karakter Disiplin Siswa Melalui Guru Kelas Di SD Negeri 3 Rejosari Kabupaten Oku Timur. JMKSP (Jurnal Manajemen, Kepemimpinan, Dan Supervisi Pendidikan), 2(2). https://doi.org/10.31851/jmksp.v2i2.1471.

Rosmiati, U., \& Lestari, P. (2021). Inovasi Model Pembelajaran PBI ( Problem Based Instruction ) Berbasis Whatsapp Sebagai Langkah Solutif Pembelajaran di Masa Pandemi Covid19. JNPM (Jurnal Nasional Pendidikan Matematika), 5(1), 188-197. http://dx.doi.org/10.33603/jnpm.v5i1.3708 Inovasi.

Sari, I., Sinaga, P., Hernani, H., \& Solfarina, S. (2020). Chemistry Learning via Distance Learning during the Covid-19 Pandemic. Tadris: Jurnal Keguruan Dan IImu Tarbiyah, 5(1), 155-165. https://doi.org/10.24042/tadris.v5i1.6346.

Sudibjo, A. (2019). Penggunaan Media Pembelajaran Ipa Berbasis Google Classroom Pada Materi Alat Optik Untuk Meningkatkan Respons Motivasi Dan Hasil Belajar Siswa Di 
Smp Negeri 4 Surabaya. Jurnal Education and Development, 7(3), 278-284. https://doi.org/10.37081/ed.v7i3.1272.

Sujatmiko, I. N., Arifin, I., \& Sunandar, A. (2019). Penguatan Pendidikan Karakter di SD. Jurnal Pendidikan: Teori, Penelitian, Dan Pengembangan, 22(1), 40-51. https://doi.org/10.24252/lp.2019v22n1i4.

Sujito, S. W., Haryanto, W., \& Lestari, W. (2015). Pengembangan Model Pembelajaran Seni Lukis Berbantuan Aplikasi Tux Paint Guna Meningkatkan Kemampuan Menggambar Alam Di Sekolah Dasar. Journal of Research and Educational Research Evaluation, 4(1), 28-33. https://journal.unnes.ac.id/sju/index.php/jere/article/view/6929.

Sumindar, A., \& Lestari, W. (2012). Model Pembelajaran Moving Class Mata Pelajaran Seni Budaya Dan Implikasinya Terhadap Kemandirian Siswa (Kajian Kasus) Di Sma Karangturi Semarang. Catharsis: Journal of Arts Education, 1(2). https://journal.unnes.ac.id/sju/index.php/catharsis/article/view/861.

Swandar, R. (2017). Implementasi Pendidikan Karakter Religius di SD Budi Mulia Dua Sedayu Bantul. Laporan Penelitian, Yogyakarta: PGSD, Universitas PGRI Yogyakarta.

Tanto, O. D., Hapidin, H., \& Supena, A. (2019). Penanaman Karakter Anak Usia Dini dalam Kesenian Tradisional Tatah Sungging. Jurnal Obsesi: Jurnal Pendidikan Anak Usia Dini, 3(2), 337. https://doi.org/10.31004/obsesi.v3i2.192.

Wuryandani, W., Fathurrohman, F., \& Ambarwati, U. (2016). Implementasi Pendidikan Karakter Kemandirian Di Muhammadiyah Boarding School. Jurnal Cakrawala Pendidikan, 15(2), 208-216. https://doi.org/10.21831/cp.v15i2.9882.

Yuliani, E., \& Saputri, R. K. (2021). Perbandingan Penggunaan Platform Google Classrom dan Grup Whatsapp Dalam Pembelajaran Online Selama Pandemi Covid-19. Jurnal Educatio FKIP UNMA, 7(1), 238-243. https://doi.org/10.31949/educatio.v7i1.934. 